\title{
The Middle-Income Trap in the Perspective of the Austrian Capital Theory
}

\section{A Armadilha da renda média na perspectiva da Teoria Austríaca do Capital}

\author{
La trampa de la renta media en la perspectiva de la Teoría Austríaca del Capital \\ Antony P. Mueller - Universidade Federal de Sergipe (UFS), antonymueller@gmail.com
}

Palavras-chave:
Armadilha de renda
média; mercados
emergentes; economia
austríaca, teoria do
capital;
empreendedorismo;
política de
desenvolvimento;
crescimento econômico.

\section{Keywords:}

Middle-income trap; emerging markets;

Austrian economics; capital theory;

entrepreneurship; development policy; economic growth.

Palabras clave: Trampa de renta media; mercados emergentes; economía austriaca; teoría del capital; emprendimiento; política de desarrollo; crecimiento económico.

Recebido em: 16-jun-2018 Aprovado em: 17-set-2018

\begin{abstract}
RESUMO
Esse artigo aplica a teoria austríaca do capital ao problema sobre as razões em que as economias emergentes caem na armadilha da renda média e o que pode ser feito para evitá-la. A análise coloca a ação empreendedora no centro, com foco na natureza subjetivista do capital e no papel do empreendedor como criador da estrutura de capital baseada em suas expectativas e em seus conhecimentos. A tese central diz que quando um país em desenvolvimento se aproxima do limite inferior ao nível de renda dos países industrializados em seu processo de recuperação e não abre a sua economia para livres mercados e empreendedorismos, mais o progresso econômico fracassará, e o país se manterá na faixa de renda média. O estudo identifica os maus investimentos em grande escala induzidos por políticas governamentais, como o principal culpado por um país ficar preso na armadilha da renda média. A conclusão política da análise é que a saída da renda média requer menos e não mais intervenção. Ao invés de mais gastos do governo, menos gastos são necessários e, em vez de promover algumas grandes empresas, o país precisa abrir seus mercados para potencializar a ação empreendedora.

\section{ABSTRACT}

This paper applies the Austrian capital theory to the problem why emerging economies fall into the middle-income trap and how they may escape. The analysis puts entrepreneurial action at the center with a focus on the subjectivist nature of capital and on the role of the entrepreneur as the creator of the capital structure based on expectations and his imagination. The central thesis says that when a developing country has come close to the lower bound of the income level of the industrialized countries in its catch-up process but does not open its economy to free markets and entrepreneurship, further economic progress will fail, and the country remains in the middleincome range. The paper identifies grand-scale malinvestments induced by government policies as the main culprit for a country to become stuck in the middle-income trap. The policy conclusion of the analysis is that the way out of the middle-income requires not more, but less intervention. Instead of more government spending, less spending is required and instead of promoting a few big companies, the country must open its markets to the full potential of
\end{abstract} entrepreneurial action.

\section{RESUMEN}

Este artículo aplica la teoría austríaca del capital al problema sobre las razones en que las economías emergentes caen en la trampa de la renta media y qué se puede hacer para evitarla. Este análisis plantea la acción emprendedora en el centro, con foco en la naturaleza subjetiva del capital y en el papel del emprendedor como creador de la estructura de capital, basada en sus expectativas y en sus conocimientos. La tesis central dice que cuando un país en desarrollo se acerca al límite inferior del nivel de la renta de los países industrializados, pero no abre su economía, ni se vuelve más emprendedor, no habrá progreso económico y el país se mantendrá en la renta media. El estudio identifica las malas inversiones inducidas por políticas gubernamentales como el principal culpable por un país quedarse atrapado en la trampa de la renta media. Las cosas empeoran cuando el gobierno, con el objetivo de deshacerse de este problema, aplica estímulos monetarios y fiscales. Tales políticas expansivas prolongan y profundizan el estancamiento. De hecho, esas políticas son del mismo tipo de aquellas que, originalmente, empujaron al país hacia esa trampa. La conclusión política del análisis es que la salida de la renta media requiere menos intervención. En vez de más gastos del gobierno, menos gastos son necesarios y, en vez de promover algunas grandes empresas, el país necesita abrir sus mercados para potenciar la acción emprendedora. El gobierno debe deshacerse de las medidas expansionistas de política económica, pues ellas inducen y profundizan el desajuste de la estructura de capital del país. 


\section{INTRODUCTION}

The analysis of the middle-income trap in the light of the Austrian theory of capital reveals that the emerging country's stagnation is the result of the continuation of the policy concept that has guided the take-off process, but it is no longer adequate. Particularly in those countries, where the take-off came about through a government-led industrialization based on the imitation of the technologies of the advanced economies, there is a tendency on continuing with state interventionism, sometimes at an even greater scale than before.

On its way of catching-up to the rich countries, the emerging economy comes to a point when imitation does no longer function because the paths ahead of the technological development are that much hazier and harder to identify, the closer the economy moves to the forefront of innovation. The developing country's economic and political leadership during the catch-up phase came into power in an age of apparent certainties about the country's development strategy and will fail now to deal with the challenges of ignorance and uncertainty. In this respect, the phenomenon of the middle-income trap has the political aspect of the unwillingness or incapability of the emerging economy's leadership to adapt to and to accept the new conditions.

The policy concepts that result from the Keynesian and neoclassical frameworks are inadequate to address the problem of the middle-income trap. Different from the Austrian school of economics, these policies focus on aggregates or on optimization and miss the fundamental roles of entrepreneurship and of the capital structure. The Austrian theory of capital distinguished itself through its focus on the heterogeneity of capital and on the role of the entrepreneur in shaping the capital structure.

\section{CONCEPT OF THE MIDDLE-INCOME TRAP}

The middle-income trap denotes the growth trajectory of a developing country that achieves high growth rates in the take-off phase, but it falls into a low-growth trajectory when the emerging economy reaches the middle-income bracket. Such countries are prone to fall into the cycle of bad policies when the economic stagnation and the failures to bring about a recovery induce ill-designed policies and bring about a populist political environment (DORNBUSCH, 1990).

On the way to turn into a rich economy, many developing countries get caught by the socalled 'middle-income trap'. After a spurt of rapid development when these countries surpass the poverty trap and the population trap, and the path seems open to reach the high-income level, 
economic growth begins to falter, and the economy does not surpass the middle-income range to become high-income countries.

While the concept of 'middle-income trap' lacks full theoretical and empirical stringency (LARSON, 2016) in the Keynesian and neoclassical perspective, the Austrian approach can identify the causes of the problem and provide useful heuristics to analyze the nature of the challenge that a developing country faces as it moves up on the income ladder.

The middle-income trap, in this sense, occurs when an emerging country enters a period of low growth after it has completed its 'take-off' (ROSTOW, 1956) and has overcome the poverty trap and the population trap (GLAVAN, 2008). Having reached the medium-income level, the steep trajectory of economic growth of the past is no longer sustainable and the country enters a phase of a prolonged period of stagnation (see Figure 1).

Figure 1: Concept of the Middle-income trap

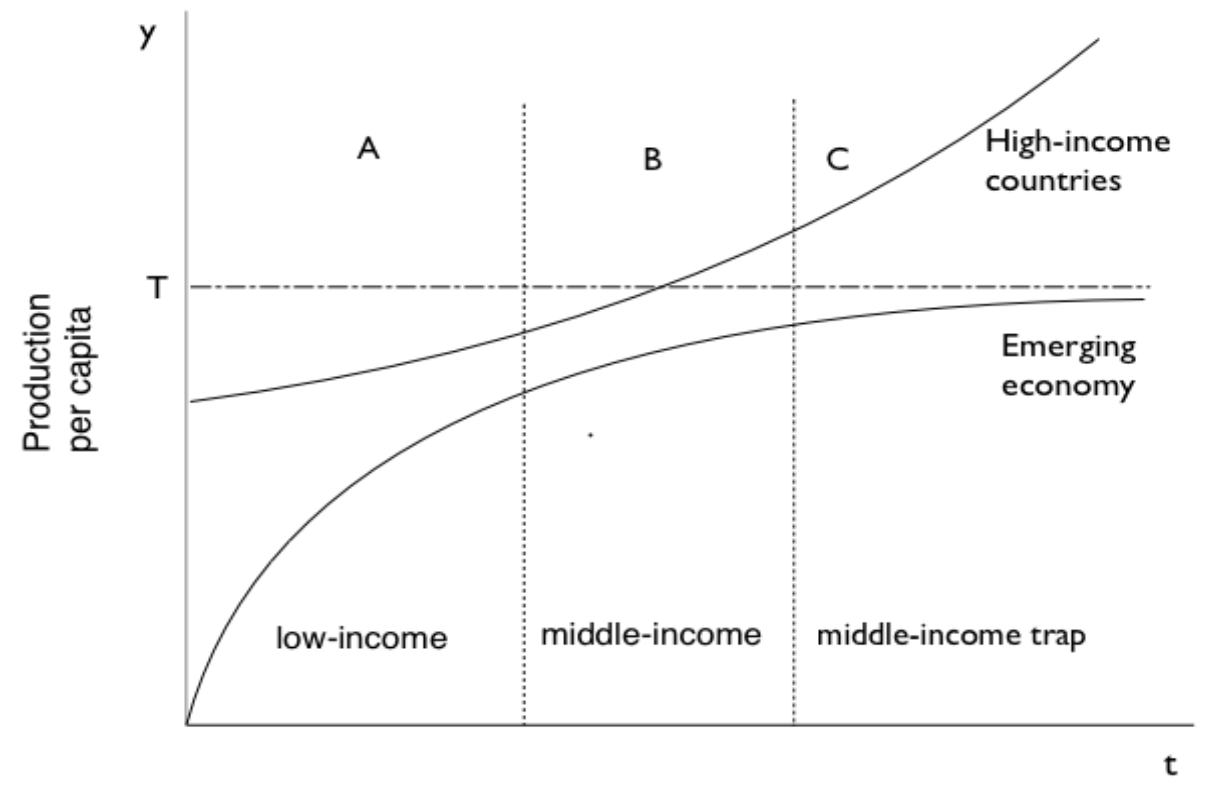

Source: Elaborated by the author

The graph (Figure 1) that is elaborated here, shows the growth trajectory in terms of production per capita of a developing country compared to the trajectory of the high-income countries. During the take-off phase (stage $A$ ), cheap labor fuels rapid economic expansion because of the migration from rural areas to the industrial centers. At this stage, the economy grows by migration, agglomeration, and capital accumulation (SHENOY, 1991). Economic growth rates are high because labor is plentiful and cheap, and capital accumulation still generates high returns 
(stage $A$ in Figure 1). Growth rates begin to fall as labor becomes less abundant and the return on capital becomes marginally smaller.

For the rich countries, the growth of the product per capita $(y)$ over time $\left(\frac{d y}{d t}\right)$ grows with an average rate of $r$ :

$$
\frac{d y}{d t}=r Q
$$

For an emerging economy, seemingly exponential growth only happens in the catchup phase, and when the product per capita $(y)$ attains a specific limit $(T)$ the curve thereafter becomes flat at the level of $\mathrm{T}$ :

$$
\frac{d y}{d t}=r y\left(1-\frac{y}{T}\right)
$$

The growth curve of the rich countries is exponential while the country that falls into the middle-income trap faces a logistic growth curve. While the high-income countries continue their expansion at relatively stable growth rates, the developing country, which in the first stage $(A)$ had higher growth rates than the developed countries and similar growth rate as the rich countries when the developing country reached the middle-income stage, its growth rates slowdown in the next stage (stage $B$ in Figure 1).

While the high-income countries continue to grow, the emerging economy remains in the middle-income range. The gap to the high-income countries, which has narrowed in the first stage $(A)$, now begins to widen when the emerging economy falls into the middle-income trap (stage $C$ in Figure 1). The model suggests that these catch-up and fallback processes may happen several times so that after the take-off and fall into the middle-income trap, the emerging economy will begin a new catch-up run when the distance has become large again and a new imitation phase is feasible. This concept would show up in the model (Figure 1) as an upward shift of $T$ along with the country's logistic growth curve.

While the mainstream approach to the middle-income trap is at a loss in explaining the sudden stagnation that befalls many countries on their development path, the Austrian approach identifies clearly the lack of entrepreneurship as the reason. The more the emerging economy advances and approaches the advanced economies, the more business must engage in an active search of its own for the next technology and new marketable products.

Stuck in the middle-income trap means that the country has not succeeded in changing its growth strategy from an imitative model to one of a competitive, entrepreneurial and innovative economy. Simple imitation of the advanced economies generates high returns only when the knowledge gap between the emerging economy and the advanced countries is large. When distance 
decreases, imitation becomes more difficult and riskier. The future is unknown and requires experimentation to discover which technologies will work. As the certainty of imitation vanishes, the new trajectory requires trial and error, which implies much more sophisticated skills than merely copying the mature technologies under state-led development. The failure of industrial policies has its roots in this discrepancy (FELIPE, 2016).

A side effect of government-led growth is typically a widening of the public sector. As the country reaches the middle-income range, the state sector turns increasingly into a barrier against the advancement of the country into the high-income bracket. Things get worse when the governments maintain their misguided interventionism (BARBIERI, 2013) if the transition to a competitive economy finds popular resistance on the part of the powerful apparatus of state-owned enterprises and the political class (EASTERLY, 2002). When the take-off had come along with an expansion of state activity, the presumption often prevails that more state control instead of less would be the answer to respond to the slowdown. Yet the consequence of this policy is not economic growth but clientelism, corruption, and the misallocation of resources (KURER, 1993).

\section{EVIDENCE}

For the 2018 fiscal year, the World Bank (2018) defines, based on the World Bank Atlas Method, the economies with a gross national income (GNI) per capita between \$1,006 and \$3,995 as "lower-middle income", while the "upper middle-income" countries are those economies with a GNI per capita between $\$ 3,959$ and $\$ 12,235$. "High-income" countries are those countries, which have a GNI per capita of $\$ 12,236$ or more, while the "Low-income" countries are those with a gross national income per capita of $\$ 1,005$ or less in 2016 (see table 1).

Table 1: World Bank country classification

\begin{tabular}{|l|c|l|}
\hline Category & Classification range (GNI) & Examples from Latin America \& Caribbean \\
\hline Lower-income & $1,005 \$$ & Haiti \\
\hline Lower middle-income & $1,006 \$<3,955 \$$ & Guatemala \\
\hline Upper middle-income & $3,956 \$<12,235 \$$ & Brazil \\
\hline High-income & $\geq 12,236 \$$ & Chile \\
\hline
\end{tabular}

Source: World Bank Country and Lending Group: Country Classification and current classification by income (2018) 
The empirical evidence of a middle-income gap is relatively clear. According to World Bank estimates (WORLD BANK, 2012 ), only 13 countries out of 101 middle-income economies in 1960 became high income by 2008. A later study (WORLD BANK, 2017) confirmed these finding (Figure 2).

Figure 2: Comparison of income groups 1970 to 2010

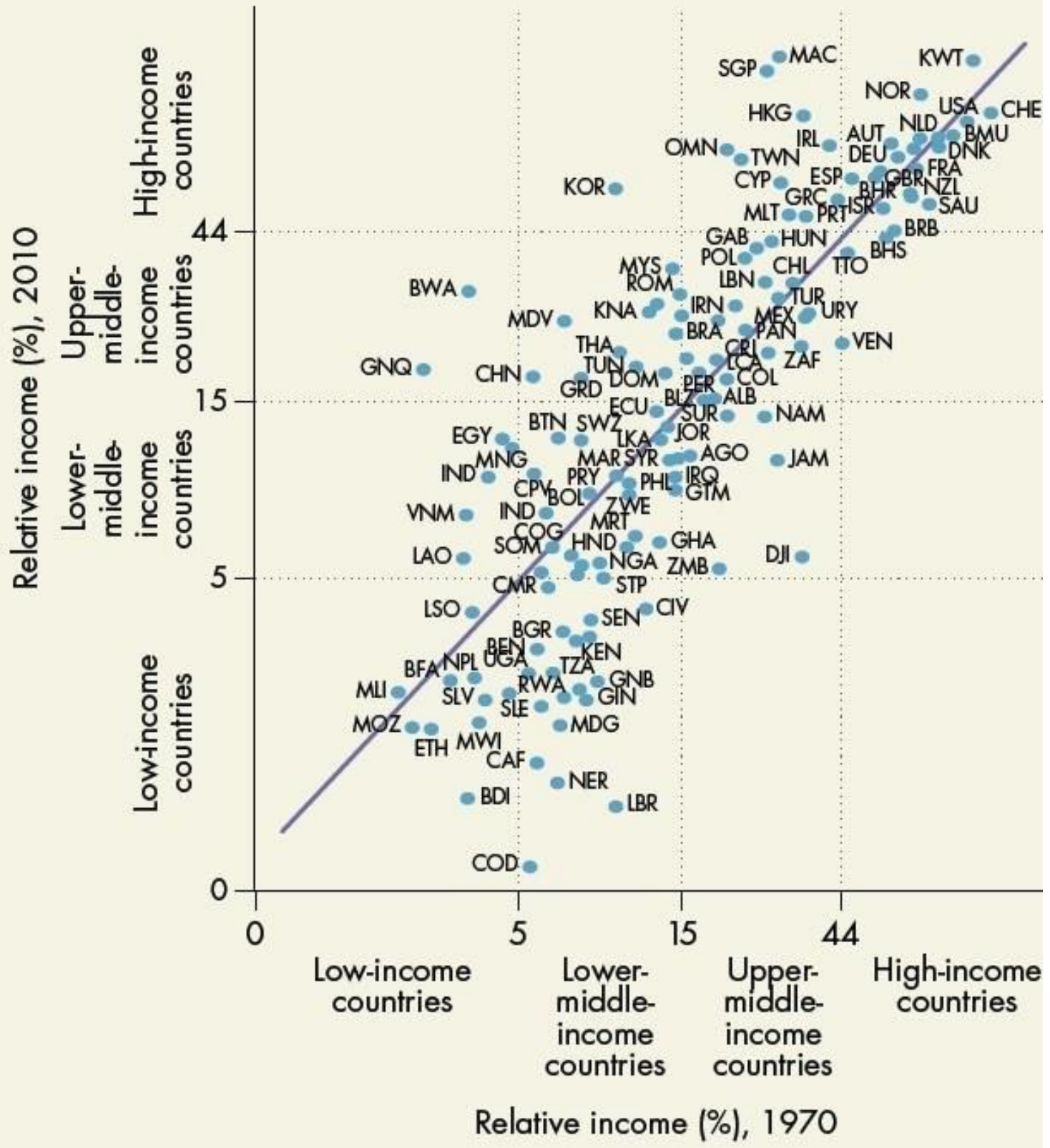

Source: World Bank. WDR 2017 team, using data from Penn World Table, version 8.1 (FEENSTRA; INKLAAR; TIMMER, 2015). 
An empirical study by Eichengreen (2013) finds that there exist two modes of income levels when the slowdown occurs, one at around ten to eleven thousand dollars income per capita and the other at fifteen to sixteen thousand dollars income per capita. This means that the slowdown of developing country growth may take place in steps rather than at a single level. Latin America shows a widening gap in comparison with the advanced economies. Per capita income relative to the United States has fallen to 0.65 in 2005 in relation to an index point of 1 in 1960 (WORLD BANK, $\left.\underline{2012^{b}}\right)$.

The dominant policy view analyzes the middle-income trap in terms of deterioration of macroeconomic aggregates. The World Bank $\left(2012^{c}\right)$ diagnoses the origin of the middle-income trap as a constellation when the pool of transferrable unskilled labor is exhausted, real wages in urban manufacturing rise, and gains from importing foreign technology diminish. Productivity growth from the sectoral reallocation and the technology catch-up are exhausted. International competitiveness erodes, output and growth slow down, and the economies become trapped in the middle-income range, unable to transcend to high-income status. Different from the Austrian view, this perspective does not identify entrepreneurship and the heterogeneity of capital as the crucial variables. Therefore, the official approach as it comes from the international organizations does not provide the adequate recipe.

The Austrian story is quite different. According to this theory, a simple imitation of the advanced technologies peters out as the country moves from the low-income to the middle-income status. This transition often happens under political leadership and comes along with the creation of a state bureaucracy. Yet the next stage, when simple imitation is no longer possible, requires the transformation of the economy from state capitalism to entrepreneurial capitalism. In the Austrian perspective the liberalization of markets, the opening-up of the society for entrepreneurial creativity, sending out, so to speak, a myriad of entrepreneurs to act as scouts to explore the unknown terrain, are the key to economic progress and development.

For many countries, particularly in Latin America, this usually means that government should do less than more, that what is needed is more free market and less State, more entrepreneurs than bureaucrats, more spontaneous creativity than control and organization. It comes as no surprise that the interventionist State as it blooms in Latin America that is excessively active in meshing with the economy is notoriously inefficient and weak when it comes to maintain the original state functions such as securing life and property.

The common characteristic of the countries that remain stuck in the middle-income trap is the combination between political populism and state capitalism (NALLARI, 2011). These countries suffer from a permanent fiscal drag, low productivity, and an 'obese' state. Into this 
category fall many countries in Latin America, including Brazil (CANUTO, 2018). Populism is the result of a political culture where the overwhelming part of the population attribute to 'capitalism' the evils for which they demand political solutions when, in fact, the deficiencies these voters complain about are the result of state interventionism. Frédéric Bastiat (1848) famously characterized the populist view of the state as "that great fiction by which everyone strives to live at the expense of everyone else".

A precarious fiscal situation is the permanent feature of these countries because any fiscal respite (typically as the result of a commodity boom) leads to more public spending. A booming economy leads to public spending because there is money in the treasury and a bust provokes public spending because of the misery. In a system characterized by populism, politicians use the government power to drain the productive economy and redistribute the resources to their followers. Such a state struggles permanently in an ongoing ambivalence with too much state on the one hand and too little populism on the other. If populism becomes too strong, the economy will collapse and when populism should recede, the politicians lose their clout.

The cost of the populist state capitalism is enormous. This becomes quite clear when one considers the extent to which once blooming countries were torn into the abyss. Argentina (CACHANOSKY; PADILHA, 2018), for example, was one of the richest countries in the world from the 19th to the mid-20th century. Then the country got into the maelstrom of populism from which it has not yet recovered. Under the presidency of Juan Domingo Perón and, after his death, during the presidency of his third wife, Argentina experienced frolic spending for social purposes and glitter until a military put an end to their reign. Yet it did not take long when the 'peronismo' returned and its representatives could gain power again. Yet while Peron and his wife were able to distribute the amassed wealth of the past, the Peronists thereafter could only distribute misery under the slogan of 'justice'.

Similar to what happened to Argentina is taking place in Venezuela, Bolivia and Brazil. With few exceptions, the entire Latin-American subcontinent is plagued by populism. With his utopia of socialism for the 21st century, Hugo Chavez (1954-2013) ruined his country. Like in Argentina, Venezuela's troubles began early (HAUSMANN; RODRIGUEZ, 2015) as it became common to spend the oil wealth without consideration of future needs. Now, the oil wealth is gone but the socialist government is still in power and promises a just distribution of the misery.

For economic growth to happen, capital accumulation is not enough. Neglecting this aspect was the great error of the Brazilian planners (FURTADO, 1999) under the influence of CEPAL - the United Nations Economic Commission for Latin America. The Austrian approach, in contrast, states that while capital accumulation is a necessary condition, it is not a sufficient condition for 
economic development. Many of the severe failures of development policy (BAUER, 2000) can be pinpointed to this aspect.

Brazil is the country of Latin America that has made the most progress in industrialization and at the same time has an immense wealth of raw materials and agricultural resources. After a great advancement of industrialization in the 50 s and $60 \mathrm{~s}$, the country fell into the trap of foreign loans and became a victim to the international debt crisis. After the lost decade of the 1980s, the country slowly regained its ground and in the second half of the 1990s with a currency reform, privatization and expenditure control. But as soon as the crisis was over, populism emerged again.

Brazil (MUELLER, 2013) put itself into its misery through Keynesian development policy. Expansionary fiscal and monetary policies to get out of the middle-income trap have brought no relief, but exacerbated the problem. Keynesian policies lead to imbalances between savings, investments, spending, and the exchange rate. Without technological progress to offset this gap, the economy will not recover. Even worse will be the situation if the government widens the budget deficits as this lowers the amount of macroeconomic savings. The macroeconomic policies of the countries that remain in the Middle-Income Trap, Brazil included, suffer from the same error that Mises had denounced by the allegory of the master builder who tries to build a house in a size that exceeds the true dimension of available resources (MISES, 1912a).

The government headed by former union leader Luís Inácio Lula da Silva turned populist state capitalism into the leading economic model. Fueled by a commodity boom and the deepening economic symbiosis with China, President Lula and his workers' party pursued an economic model whereby mass consumption became the driving force of the boom. The Brazilian government launched a redistribution program that would provide public money to millions of families. This policy of almsgiving was praised by almost all sides, including foreign observers and international institutions. At the height of the populist wave towards the end of his second term in 2010, Lula da Silva was able to boast of high growth rates and full employment. Since 2011, however, the economy has been sinking. Instead of catching-up to the advanced economies, Brazil is falling back again. The mean economic growth rate of the past five years is in negative territory and the unemployment rate has reached more than 12 percent since 2017. In terms of economic freedom, Brazil ranks at number 153 between Uzbekistan and Afghanistan (HERITAGE, 2018).

Brazil represents a case where entering the middle-income trap has resulted in a series of inadequate policies that have worsened the situation. The next big test case is how China will fare in the face of slower growth in the future (SCHNEIDER, 2013). The outlook is bleak when one considers that of the few countries that made it to the higher-income group, many of these countries did so at least in part because of special factors such as becoming a member of the European Union 
(Portugal, Spain, Greece, Ireland) or because of special geostrategic relation with some highly developed country. Mainly by their own efforts, only the high-income Asian countries did so because of their transition to an entrepreneurial economy (AUGUSTIN-JEAN, 2010).

\section{THE AUSTRIAN PERSPECTIVE}

While there is no specific 'Austrian theory of economic development', Austrian economics has a rich body of concepts that may help to clarify the fundamental challenges of economic development (MANISH, 2015). The literature about capital and the business cycle provides an ample arsenal to analyze the problems associated with the middle-income trap.

Austrian economics - as its unifying theme ${ }^{1}$ - rejects mechanistic modelling in favor of a theory of human action. Human action is seen as individualist action which is based on subjective value judgements. Human action as purposeful and implicitly rational behavior sets it apart from behaviorism and strict determination. The organizing principle of human experience is the individual and not external observation. The central laws of human action are to be found a priori, and not a posteriori. In this form, the laws of human action have apodictic validity; they are not contingent to experience, but they are the logical implications of the premise that 'man acts'.

Because the complexity of action cannot be observed, or isolated, empirical statements can neither confirm nor refute a theoretical sentence about human action². By making human action - in contrast to the decision-making-approach - the central theme of economics, various aspects that are specific of the Austrian approach enter the realm of investigation, foremost among them: individualism, time, sequence, uncertainty, and adaptation.

The main feature of Austrian economics is its radical individualistic-subjective approach to economics, including macroeconomics. While Austrian economics shares many elements with neoclassical economics, there are also several aspects, which make it unique and distinct. If one should distinguish the Austrian school by one major criterion, it would be 'human action', and this concept would stand in contrast to 'equilibrium'. The concept of 'human action' is the distinguishing factor that separates Austrian economics from neoclassical formalism and the hypostatization of Keynesian aggregate analysis. Averages and aggregates cannot serve as determinants as they do

\footnotetext{
1 See Ludwig von Mises, Nationalökonomie. Theorie des Handelns und Wirtschaftens, Genf (1940) and the English version scholar's edition: Human Action, Auburn, Alabama (1998) as well as Murray N. Rothbard, Man, Economy, and State: A Treatise on Economics, Princeton, N.J. (1962).

2 "Behavioristic laws" are not statements about human action just as psychology, medicine or body chemistry do not deal with human action as it is defined by Austrian economics. Laws or propositions found in these disciplines are no more economics than technology or the laws of physics that rule a production process. The Austrian approach is quite strict in defining economics and sets it also apart from motivations research.
} 
not provide causal relationships. It is scientifically invalid to establish causal relationships among aggregates and averages. Such an approach imposes an inadequate model of science on the study of society.

Value and rationality are intimately linked to individual subjectivity. Human action is guided by meaning; it is anchored in the thinking of the individual. Human knowledge is basically individual, subjective, heterogeneous, disaggregated, private, largely tacit, and necessarily incomplete. Assumptions, constructs and ideologies substitute for this incompleteness. Human action contains the tendency to err. That markets fail (with respect to the criteria of the nirvana theory of neoclassical equilibrium analysis) is as simple as the observation that any human action is inherently erroneous, making continuous adaptation the foremost mark of economic activity. Markets are means of coordination and represent a continuous process of discovery ${ }^{3}$.

Although capital and entrepreneurship play an essential - maybe the essential - part in the everyday workings of the modern economy, the role of capital and entrepreneurship are almost entirely absent in the mainstream version of modern macroeconomics. It is in Austrian economics that capital and entrepreneurship play a prominent role. The capital structure in terms of the stages of production provides the foundation for the formulation of the Austrian theory of the business cycle which continues to be a major topic in the Austrian research program. Hayek $\left(1941^{\mathrm{a}}\right)$ made decisive steps forward to purify the concept of capital from some of its objectivist attributes but failed to integrate entrepreneurship into his theory, probably because his focus was oriented towards macroeconomics to obtain a foundation of his business cycle theory.

The attention paid to capital in its relation to time lies at the heart of Austrian macroeconomics. Based on Böhm-Bawerk's concept of capital (BÖHM-BAWERK, 1884a) and the Mises-Hayek's business cycle theory (MISES, 1912 ; HAYEK, 1931, 1941 b $)$, Garrison (2001, 2005), Selgin (1997), Salerno (2010), de Soto (1998), Lewin (1999), Cowen (2002). Horwitz (2000) and Mueller $(\underline{2014}, \underline{2018})$ have advanced the Austrian capital theory in the context of the business cycle.

Beginning with Böhm-Bawerk $\left(1884^{\mathrm{b}}\right)$, the heterogeneity of capital as an ordered production structure forms the starting point for the Austrian theory of capital. Many fruitless disputes have emerged because the critics of the Austrian theory of capital did not recognize this point of departure and instead, they have continued using a concept of capital as if it were homogenous and as such measurable in real terms simply by deflating the nominal aggregate.

As Böhm-Bawerk explained, “...capital is the sum of heterogeneous concrete capital goods. To aggregate them, one needs a common denominator. This common denominator cannot 
be found in the number of capital goods, ... nor their length or width or volume, or weight or any other physical unit of measurement. The only measuring rod that does not lead to contradictions... is the value [of these capital goods]" 4 .

The Austrian tradition treats capital not as a homogeneous entity, but as a process that is ordered and structured by entrepreneurial plans and refers to heterogeneous production goods. The heterogeneity of capital implies that the capital structure is built up as combinations consisting of complementary elements that are arranged by an entrepreneurial vision (LACHMAN, 1956, p. 12). The logic of capital is the vision of the entrepreneur who arranges the capital goods in a way that he deems appropriate to meet future demands.

What is it, Lachmann (1956a , p. 15) asks, that unites capital in its concrete representation such as it shows up as "(b)eer barrels and blast furnaces, harbor installations and hotel-room furniture" other than the entrepreneurial plan and the valuations that are derived from this plan? The arrangements that take place are arrangements in terms of an order guided by a purpose. It is a process of valuation that extends from the expectations, a vision of the future, to the present. The valuation of capital is not causal but teleological and volitional, and it is grounded in human action with its basic elements of time, stages, and purpose.

In contrast, neoclassical macroeconomics puts the capital structure in a black box from where the output emerges as a functional relationship. From this the divide between micro- and macroeconomics has emerged that relegates production and cost analysis to microeconomics and elaborates the exchange features, while macroeconomics deals with the large aggregates consumption, investment and government expenditures - or the price level and real and nominal national income aggregates. In this respect, there is little difference between the "economics of Keynes" and the hyphen-Keynesian and the new hyphen-classical economists and monetarism.

Modeling capital as heterogeneous represents a fundamentally different perspective compared to standard neoclassical modeling. The concept of roundaboutness as the time that is required to gain higher productivity, and the heterogeneity of capital, it is brought to light that the outcome of investment requires waiting and as such investment is confronted not only with risk, but with uncertainty in the sense of unknown distributions of the results. In this perspective, the role of

\footnotetext{
4 Translated quotation from Böhm-Bawerk's "Capital and Interest" in Hennings (1997, p. 132). Interestingly enough, Piero Sraffa, one of the major intellectual forerunners of what is now called "post-Keynesian" economics, put the problem quite succinctly in a letter to Joan Robinson of October 1936, although even his belated recognition after what Böhm-Bawerk had already said almost 40 years earlier seems to have met deaf ears not only by Joan Robinson regarding Sraffa's reminder that "(if) one measures labor and land by heads or acres the result has a definite meaning; subject to a margin of error. On the other hand, if you measure capital in tons the result is purely and simply nonsense... If you are not convinced, try it on someone who has not been entirely debauched by economics. Tell your gardener that the farmer has 200 acres or employs 10 men - will he not have a pretty accurate idea of the quantities of land \& labour? Now tell him that he employs 500 tons of capital \& he will think you are dotty - (no more so, however, than Sidgwick or Marshall)." Quoted in King (2002, p. 80-81)
} 
the entrepreneur comes into play as to his specific function as the anticipator of the unknown future demand and price structure and therefore as the preeminent economic agent whose prime specialization lies in dealing with uncertainty.

The neglect of entrepreneurship has its roots in the negation of uncertainty. An economic policy that puts a blind eye on uncertainty and entrepreneurship promotes its own disaster. Economic theories that treat capital (if it is mentioned at all ${ }^{5}$ ) as something that has been already produced and exists in a homogeneous form that can be simply increased by more capital investments to compensate for depreciation and to expand the capital stock avoids the confrontation with uncertainty. The users of these models reduce the economic problem mainly to exchange and neglect the many relevant problems that result from the uncertainty about the future.

In modern macroeconomic growth theory, investment is treated as an addition to capital which would happen without a change of the underlying capital structure. It is assumed that it would be possible to make a clear separation between the different factors of production as to their specific contribution to output. In this framework, it is assumed that these factors could be neatly separated and that there is no connection between capital and the human entrepreneurial mind. This approach is incapable of recognizing that the production of capital requires first an entrepreneurial idea, and that production comes into existence through human action based on an idiosyncratic and on an ex ante improvable view about future market conditions.

The conventional macroeconomics can be condensed as to its basic structure into a production function that relates the factors of production to the output and the Keynesian aggregation with its sub-aggregates consumption, investment, and government expenditure. The relationship of the Keynesian aggregation of a closed economy with the equation of exchange shows up when by decomposing the expenditures into their price and quantity factors. Modified through the lens of the equation of exchange - which relates money $(M)$ and its velocity $(V)$ to output $(Q)$ and prices $(P)$, the formula for the Keynesian aggregates consumption $(C)$, investment $(I)$, and government expenditures $(G)$ would read:

$$
\begin{gathered}
M \times V=Q \times P=Y \\
Y=C+I+G \\
Y=C_{P} \times C_{Q}+I_{P} \times I_{Q}+G_{P} \times G_{Q}
\end{gathered}
$$

5 A textbook, for example, that carries the promising title "Recessions and Depressions. Understanding Business Cycles", there is no entry for "capital" in the index, and the few times "capital" is mentioned at all, it is in the meaning of "capital flows". See Knoop $\underline{(2004)}$ 
The Keynesian approach provides an ex-post picture including money and prices, but it does not open the black box and show how the economy works as a process of interaction among individual economic decision-makers. As it is also the case with the Keynesian models in general, the theory delivers a notion how matters end but not how they come about. In this regard, the Keynesian framework resembles accounting. Here, too, we are told about how the period ended in terms of profit and loss and the balance shows us the components, but this approach does not inform about the underlying reasons and causes for the results. To know how the result came about and to teach a lesson for future action, one must look at the business management. Likewise, at the level of the macro-economy, the Keynesian theory states the existence of equilibrium, but this only appears as a theoretical endpoint and does not provide a theory how the economy works as a process.

In contrast to the Keynesian approach, Austrian economics contains the theory about the dynamics of the economy. In the Austrian version, the stream of goods is maintained by the incessant adaptation to local and temporary conditions - guided by the purposive human action to avoid losses and gain profit. The stabilizers of this system are the individual economic agents guided by relative prices (HAYEK, 1984, p.18) as they observe (information) and heed (incentive) the signals. The interest rate is the major signal to provide orientation as to the inter-temporal allocation of available funds. Probably the most important insight of Hayek's contribution to the Austrian theory of capital is that capital is scarce in the specific sense that there exist more opportunities (including technological options) than can be realized given the present state of funds as they come from savings. There is a basic trade-off in place between the demand for consumption goods and investment goods, i.e. between consumption and savings or between lower consumption now in favor of higher consumption later and higher consumption now at the cost of consumption that could otherwise have been higher in the future.

\section{CAPITAL AND THE ROLE OF THE ENTREPRENEUR}

A well-founded theory of capital is still absent in modern textbook macroeconomics. Capital appears in the growth theories mathematically simplified as the homogeneous blob that expands and shrinks according to the rates of investment and depreciation. In this objectivist view, capital exists independent from human action and entrepreneurial imagination.

The prominent Solow-Swan growth model (BARRO, 2004) incorporates a production function where the output depends on the production factors labor $(N)$ and capital $(K)$. The 
productivity rises with the technological progress $(A)$ whose value shifts the production function upwards.

$$
\begin{aligned}
& Y_{t}=A K_{t}^{\alpha} N_{t}^{1-\alpha} \\
& \frac{Y_{t}}{N_{t}}=A \frac{K_{t}^{\alpha} N_{t}^{1-\alpha}}{N_{t}}
\end{aligned}
$$

While the neoclassical production function in the Cobb-Douglass version describes the properties of economies quite well (with $\alpha=1 / 3$ ), it does not tell how the production comes about. Maybe it is no exaggeration to say that almost all difficulties of modern macroeconomics to come to grips with reality have their roots in the lack of a theory of capital. Failing to incorporate capital systematically into macroeconomic theory has deluded the theoreticians to follow pipe dreams and construct models like sand castles. This neoclassical growth model assumes that the economy's capital structure remains unchanged in the face of capital accumulation and technological progress. This implies that what matters were only capital accumulation and technology and that the capital structure would require no attention. This way, the neoclassical growth model can do without the entrepreneur. As the consequence of this lack of realism, the model has instigated a plethora of policy errors by its naïve practitioners.

Different from the neoclassical concept of capital as a homogenous entity devoid of a structure and time, the Austrian approaches views capital as heterogeneous and linked to time. From this modification, the other differences between the two concepts of capital follow. Of the leading macroeconomic paradigms, Keynesian economics has only expenditures in its focus and abandoned capital theory, and in monetarism, the real economy and its capital structure have vanished completely, while the neoclassical growth theory uses capital in an oversimplified manner.

The neoclassical growth theory stylizes capital as a stock and investment and depreciation as flows. Consequently, the replacement and maintenance of capital becomes a problem of addition and subtraction, which can take place discontinuously or periodically. Because this approach treats capital (if it is mentioned at all outside of growth theory) as something that can be increased by capital additions without changing the structure of the existing capital stock, there is no need for an entrepreneur. The decision to increase or not to increase or - when technical progress is included - which technology to apply vanishes from the analytics and the existing capital stock could be managed by an automaton or a political committee including the organs of the central government. This type of modeling eliminates the essential properties of capitalist production. 
The structural aspects of capital and the function of the entrepreneur remain in the dark. In this context, with the concept of capital as a measurable unit that supposedly represents the aggregate of capital goods, erroneous propositions emerge such as that the aggregate expenditures determine the demand for capital and labor. Because of its distorted treatment of capital, modern macroeconomics has lost its aptitude to discern one of the most fundamental problems of the business cycle and persistent stagnation: the built-up of malinvestment in the excessive boom and the re-balancing (or "re-coordination") of the capital structure in the bust.

The entrepreneur is the essential link between the market signals and the capital structure. The task of the entrepreneur is quite different from how it appears in conventional economic theory where an investment function describes the relation between the interest rate and the amount of investment flows that would happen accordingly. This approach eliminates the entrepreneurial function and provokes the caricature of the businessperson as a mindless automaton on the one side or an equally mindless creature ruled by animal spirits (AKERLOF; SHILLER, 2010) on the other side. In such a world, no visionary roundabout production can happen.

The arrangements that take place are arrangements in terms of an order guided by a purpose. This process of valuation extends from the expectations, the plan, and the vision of the future, to the present. The valuation of capital is not causal but teleological and intentional and grounds in human action with its basic elements of time, means, and purpose (IORIO, 2011).

Entrepreneurship, in this sense, is not so much "alertness" (KIRZNER, 2013) - a concept which would imply costless profits from discovery. Entrepreneurship is not mainly technical and administrative progress (HOLCOMBE, 2003) either. The entrepreneurial investment activity rather shows up as the pursuit of productivity gains, i.e. it appears as purposive action in the move

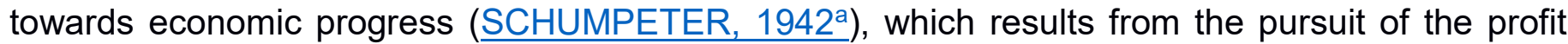
motive (MISES, 1998). This means that technical progress and the improvement of human capital lies in the act of investment itself in as much as the investment activity is guided by the entrepreneurial intention to apply changes to the capital structure as a tool to gain profit.

Hayek (1979), states that it is "probably no exaggeration to say that every important advance in economic theory during the last hundred years was a further step in the consistent application of subjectivism". Indeed, if one recognizes that capital is heterogeneous, logical consistency requires a subjectivist approach to capital and roundaboutness because the unity of the existing capital structure is no longer objectively given but will only exist in the imagination of the entrepreneur in the form of a plan. Such a perspective opens the theory of capital to uncertainty and "makes room for the creativity and autonomy of individual choice" (O'DRISCOLL; RIZZO, 1985, p. 1). The subjectivist perspective leads to a view of the economic process that is fundamentally 
different from the other approaches. The objectivist definition of capital can do no other than postulate homogeneity and throw out uncertainty and entrepreneurship, while the subjectivist theory of capital leads to a view of the capital where uncertainty, choice and entrepreneurial action not only receive due attention but become constitutive elements of the theory of capital.

The central problem of a non-Austrian theory of capital is the assumption of a homogenous and quantifiable capital stock. As Lachmann (1956 ${ }^{\text {b }}$, p. 6) points out, such a theory is "bound to ignore important features of reality". As this theory disregards the heterogeneity of capital, "the true function of the entrepreneur must also remain hidden" (LACHMANN, 1956도. p. 16). In such a theory "investment becomes merely a question of changing the absolute quantity of this homogeneous capital stock. Its composition does fragmentary." (LACHMANN, 1956, p. 49)

It is a different case with the Austrian approach6. The Austrian position holds that nonpermanence is the characteristic attribute of capital goods and thus the problem of continuous reproduction and re-structuring of capital becomes a focal point. In Austrian economics, it is "not the individual durability of a particular good but the time that will elapse before the final services to which it contributes will mature that is regarded as the decisive factor. That is, it is not the attributes of the individual good but its position in the whole time-structure of production that is regarded as relevant" (HAYEK, 1941', p.48).

As to the choice of technology, neoclassical economics assumes that the decision about which of the many known technological methods to employ depends on current supply and demand conditions, and the given state of the technology determines the technique employed in production. Likewise, this theory supposes that capital is being increased in the sense of a lateral expansion of production, as a simple duplication of the kind of capital already in existence because the homogeneity assumption provides the indispensable foundation of this approach.

In sharp contrast to the homogeneity thesis, the Austrian capital theory stresses that when companies employ additional capital, the capital structure changes and with capital, the use of the technology of production changes. Additional capital leads to structural changes of the capital, and as such, investment is not a mere addition or subtraction in relation to an existing capital stock, but new investment will transform the original capital structure.

Schumpeter (1912) put forth his theory of the entrepreneur in the context of economic development. While classical economics focused on the division and specialization of labor, and

\footnotetext{
6 Hayek (1941) denotes the opposing paradigm to his theory the "Anglo-American" concept of capital in contrast to the "Austrian" concept of capital. But the designation "Anglo-American" capital theory is rather ambiguous as Hayek himself makes it clear when he states that the classical English economists were in many aspects much more "Austrian" than their followers. Yet it is easy to avoid this notion because almost any branch of economics other than the Austrian theory has adopted the neoclassical or "AngloAmerican" variant of capital theory. Therefore, it is legitimate to differentiate between the "Neoclassical" and an approach to capital theory that can be defined specifically as "Austrian" in an effort to highlight the major differences.
} 
identified labor as the main source of productivity, the approach taken here identifies the capital structure as the source of increases in productivity. While the workman gets his pay in the form of a salary for working and the capitalist gets interest paid for waiting, the entrepreneur gets his reward in the form of profits which depend on the degree how well the entrepreneur was able to construct a capital structure that is in tune with the demand when the structure is ready to produce output. It is obvious that there can be no certainty about the value of the capital structure ex ante and thus for profit. By its very nature, profits are a residual remuneration and must necessarily be so. The good remains an investment good as long as it is not sold to the final user and only at that point in the time when it is sold, turns into a consumption good and provides the funds for the remuneration of the capitalists and the entrepreneur all the while the workers have received their salaries during the total stretch of the production process (ROTHBARD, 2001, p. 387-462).

The quintessential form of capitalist production is not capital expansion but managing changes of the capital structure. Any such an alteration, as it comes with investment, implies that some parts of the capital structure will become obsolete. The result of roundaboutness will only show up after some time. It is here that the role of the entrepreneur comes into play as the agent to specify the capital structure under the guidance of expected profit and loss. This view clarifies the role of 'technological progress' and avoids the troubles that modern macroeconomics has with increases in productivity due to new technologies or improvements of human capital.

\section{AGENDA FOR EMERGING ECONOMIES}

Emerging economies fall into the trap of middle-income because, instead of embracing innovative capitalism, they maintain a statist economic system. It is not uncommon for the old elite to exploit the population's fear of the "perennial storm of creative destruction" (SCHUMPETER, $\underline{1942^{b}}$ ) of the dynamic capitalism. To make matters worse, developing countries often suffer from rigid labor regulations which promote a large informal sector and increases unemployment, especially of young people (DJANKOV, 2009).

By opposing creative destruction, one also ends up rejecting prosperity and feeds the illusion that it is possible to become rich within a statist system. In fact, developing countries that maintain state capitalism do not only gain prosperity, but also lose stability when they inevitably fall into the vicious circle of economic decline, causing the political system to begin to oscillate between authoritarianism and populism.

To get out of the middle-income trap, the developing country must perform a fundamental transformation in its economy. The country must move from a cumulative and imitative economy to 
an innovative economy. Instead of a top-down transformation, the economy needs to blossom at the bottom (PHELPS, 2015). The way out of the middle-income trap cannot be made through more government but must be led by private entrepreneurship. This change requires the elimination of the regulatory and bureaucratic obstacles that hold back the entrepreneurial spirit. Reducing the tax burden and eliminating the bureaucratic nightmare are essential. The government must abandon its ad hoc interventionism in favor of a policy that facilitates entrepreneurship.

Outside of Austrian economics, the subjective, structural and time-consuming aspect of capital formation gets neglected and with it comes the view that it is purely quantitative additions or subtractions to an existing capital stock that would count in the process of capital accumulation. Along with this view, many other aspects also get lost such as that capital formation is highly vulnerable to detrimental policy interventions. It is widely accepted that negative legal surprises will induce the entrepreneur to cut back on the degrees of roundabout processes or refrain from initiating them. However, monetary policy changes will also distort the basis of economic calculation. The interest rate plays a central role in the entrepreneurial decision if and to what extent roundabout production will be initiated and to what extent the project will result in success or failure. Typically for the occurrence of macroeconomic malinvestment is a policy interest rate that was set too low in relation to available savings and which later tends to be set too high by the monetary authorities to correct their earlier mistake. The artificially low-interest rate induces business to initiate roundaboutness while in the correction phase the higher interest rate now signals that the process has become overextended. The consequence will be that unfinished projects show up whose visible side are 'idle resources' both in the form of unused capital and unemployable labor yet whose hidden nature exists in earlier failed investments.

An unfavorable business climate will discourage the undertaking of roundaboutness and even if there are guarantees of the property rights, roundabout production will be discouraged when there are high barriers to entry and when excessive levels of taxation limit the realization of pioneer profits. It is characteristic of new production techniques that they become the standard over time and thus the advantages of innovation will have a limited lifespan. As much as there is competition between firms about finding the right product and the best product mix, the other major competitive factor is the question what kind of capital to apply. Within an unfavorable business climate, business will mainly invest in standard production and the more roundabout production procedures will be avoided. When this is the case, the economy will suffer from low productivity levels.

Innovation is accompanied by uncertainty about the outcome of the investment. These uncertainties extend beyond future demand and include changes in the overall business climate during the process of maturation until the higher productivity will show up in the goods production 
and until the profits can be realized. In an unfavorable business environment, productivity will stagnate because more roundabout production procedures will be avoided, and standard production methods tend to be maintained. The entrepreneurial plan has no other basis than the expected profits and as such an essential part of entrepreneurial action exits in imagination.

\section{CONCLUSION}

Middle-income countries, after overcoming the poverty trap and the Malthusian trap, face the depletion of cheap labor. An emerging country falls into the middle-income trap when it simultaneously loses its ability to compete with low-income countries in terms of prices and, at the same time, does not have the capacity to compete at the level of the high-income countries in terms of technology. The interference of the state in the economy causes these countries to fall into stagnation. Trying to get out of the trap using monetary and fiscal stimulus policies not only does not work, but it paves the way for public debt, and generates more economic weakness. This group of countries, of which Brazil is a prominent case, suffers from recurrent cycles of artificial economic expansion followed by prolonged stagnation. To continue to grow, the country must have technological progress. However, if the country maintains its statist policies and resorts to budget deficits and monetary inflation, the government promotes the opposite course. To achieve higher levels of productivity, the country must abandon its statist development model. In order to get out of the middle-income trap, the emerging economy must open its markets to the entrepreneurial capitalism of creative destruction.

In the perspective of Austrian capital theory, the way out of the trap is the opposite of what many emerging countries have been practicing over the past decades. Instead of more, less state intervention is required and instead of government promotion of specific enterprises under an industrial policy, one must make way for private entrepreneurship. The more the state stays at the helm of the economy, the less the entrepreneurs will have space to exert their function as the explorers of new economic opportunities. The way out of the middle-income trap is not more public spending and more public policies, but instead, a move to a lower tax burden and less bureaucratic regulation. What needs to be done to get out of the middle-income trap is the liberation of the entrepreneurial potential of the country. This requires flexible labor market, tax-incentives to reinvestment profits, and full-scale privatization in the context of competitive markets. 


\section{REFERÊNCIAS}

AKERLOF, George A.; SHILLER, Robert J. Animal Spirits: How Human Psychology Drives the Economy, and Why It Matters for Global Capitalism. Princeton University Press, 2010.

AUGUSTIN-JEAN, Louis. Entrepreneurship as a Contributor to Growth in Asia: The Case of Hong Kong. Canadian Journal of Development Studies, v. 31, p. 317-340, 2010.

BARBIERI, Fabio. A Economia do Intervencionismo. São Paulo: Instituto Ludwig von Mises, 2013.

BARRO, R. Economic Growth. Cambridge, Mass: MIT Press, 2004.

BASTIAT, Frédréric. L'etat. Journal des débats, in: Frédéric Bastiat, Selected Essays on Political Economy. Chapter 5: The State. Library of Economic and Liberty, 1848. Available at: em: $<$ https://www.econlib.org/library/Bastiat/basEss.html>. Retrieved October 16, 2018

BAUER, P. T. From Subsistence to Exchange and Other Essays. Princeton University Press, 2000.

a $\underline{b}$ BÖHM-BAWERK, E. V. The Positive Theory of Capital. Auburn: The Ludwig von Mises Institute, 1971 [1884)].

CACHANOSKY, N.; PADILHA, A. Latin American Populism in the 21st Century. July 2, 2018, Social Science Research Network (SSRN). Available at: <http://dx.doi.org/10.2139/ssrn.3147096>. Retrieved October16, 2018

CANUTO, O. How to heal the Brazilian economy. EconMonitor. September, 2018. Available at: $\quad<$ https://moneymaven.io/economonitor/latin-america/how-to-heal-the-brazilian-economyiAYiZQFWd0GR86s1WN45qQ/>. Retrieved October 16, 2016

COWEN, T. Creative Destruction: How Globalization Is Changing the World's Cultures. Princeton University Press, 2002.

DJANKOV, S. Employment laws in developing countries. Journal of Comparative Economics, v. 37, p. 3-33, 2009. 
DORNBUSCH, R. The Macroeconomics of Populism in Latin America. University of Chicago Press, 1990.

EASTERLY, W. The Elusive Quest for Growth: Economists' Adventures and Misadventures in the Tropics. MIT Press, 2002.

EICHENGREEN, B. et. al. New Evidence on the Middle-Income Trap. NBER Working Paper $\mathrm{n}$. 18673, January, 2013.

FELIPE, J. Development and Modern Industrial Policy in Practice: Issues and Country Experiences Reprint Edition. Cheltenham, U.K.: Edward Elgar Publisher, 2016.

FURTADO C. O longo amanhecer. Reflexões sobre a formação do Brasil. São Paulo: Paz e Terra, 1999.

GARRISON, R. W. Time and Money. The macroeconomics of capital structure. London and New York: Routledge, 2001.

GARRISON, R. W. The Austrian School. Capital-Based Macroeconomics. In: SNWDON, Brian; HOWARD, Vane. Modern Macroeconomics. Its Origins, Development and Current State: Aldershot. Edward Elgar, 2005.

GLAVAN, B. Poverty Traps, and the Market Process. A New Case for Industrial Policy? The Independent Review, v. 13, n. 2, p. 225-243, Fall, 2008.

HAUSMANN, R.; RODRIGUÉZ, F. Venezuela Before Chávez: Anatomy of an Economic Collapse. University Park, Pennsylvania: Penn State University Press, 2015.

HAYEK, F. A. Der Wettbewerb als Entdeckungsverfahren. Tübingen: Freiburger Studien, 1969.

HAYEK, F. A. Prices and Production. New York: Augustus M. Kelley, 1931.

$\underline{a} \underline{b} \underline{c}$ HAYEK, F. A. The Pure Theory of Capital. Chicago: University of Chicago Press, 1941. 
HAYEK, F. A. Scientism and the Study of Society. In: The Counter-Revolution of Science. Indianapolis: Liberty Press, 1979.

HAYEK, F. A. Intertemporal Price Equilibrium and Movement in the Value of Money. In: Money, Capital and Fluctuations. Early Essays. Chicago: The University of Chicago Press, 1984, p. 71117.

HENNINGS, K. The Austrian Theory of Value and Capital. Studies in the Life and Work of Eugen von Böhm-Bawerk. Cheltenham and Brookfield: Edward Elgar, 1997.

HERITAGE (2018). The Heritage Foundation. Index of Economic Freedom. Heritage Foundation, 2018. Available at: <https://www.heritage.org/index/country/brazil>. Retrieved October 16, 2018

HOLCOMBE, R. G. Progress and Entrepreneurship. Quarterly Journal of Austrian Economics, v. 6, n.3, fall, p. 3-26, 2003.

HORWITZ, S. Microfoundations and Macroeconomics. An Austrian Perspective. London and New York: Routledge, 2000.

$\underline{\text { IORIO }}$, U. Ação, Tempo e Conhecimento. A Escola Austríaca. São Paulo: Instituto Mises Brasil, 2011.

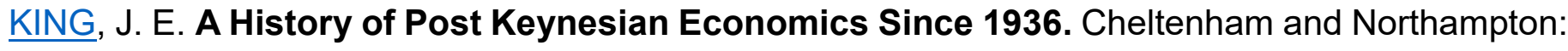
Edward Elgar, 2002.

KIRZNER, I. Competition and Entrepreneurship (The Collected Works of Israel M. Kirzner). LOCAL: Liberty Fund, 2013.

KNOOP, T. A. Recessions and Depressions. Understanding Business Cycles. Westport and London: Praeger, 2004.

KURER, O. Clientelism, corruption, and the allocation of resources. Public Choice, v.77, p. 259272, 1993.

$\underline{a} \underline{b} \subseteq$ LACHMANN, L. Capital and Its Structure. Auburn, Ala. Ludwig von Mises Institute 1956. Available at: https://mises.org/library/capital-and-its-structure. Accessed in October 16, 2018 
LARSON, G. et. al. The Middle-Income Trap: Myth or Reality? The World Bank Development Research. Research \& Policy Briefs from the World Bank Malaysia Hub, n.1, march, 2016. Available at: <http://documents.worldbank.org/curated/pt/965511468194956837/pdf/104230-BRIPolicy-1.pdf>. Retrieved October 16, 2018

LEWIN, P. Capital in Disequilibrium. The role of capital in a changing world. London and New York: Routledge, 1999.

MANISH, G. P. The Contributions of Austrian Economics to Development Economics (with Benjamin Powell). In: BOETTKE, P.; COYNE, C.(eds.). The Oxford Handbook in Austrian Economics. Oxford University Press, 2015.

a $\underline{b}$ MISES, L. v. Theorie des Geldes und der Umlaufsmittel. Auburn: Ludwig von Mises Institute, 2010 [1912].

MISES, L. v. Human Action. A Treatise on Economics. Auburn: The Ludwig von Mises Institute, 1998.

MUELLER, A. P. Facing the Challenge of Global Turmoil. The Position of Brazil in the International Monetary System. Interfaces Brasil/Canadá, v. 13, n. 16, p. 177-199, 2013.

MUELLER, A. P. Beyond Keynes and the Classics. Processos de mercado. Revista europea da economia política, v. 11, n. 2, p. 11-135, 2014. Available at: $<$ https://dialnet.unirioja.es/servlet/articulo?codigo=4980988>. Retrieved October 16, 2018

MUELLER, A. P. Capital and the Business Cycle. Macroeconomics. Prices, Business Fluctuarions \& Cycles e Journal ${ }_{2}$ v.. 11, issue 47, April, 2018. Available at: $<$ https://papers.ssrn.com/sol3/papers.cfm?abstract id=31414477>. Retrieved October 16, 2018

NALLARI, R. The Role for State Intervention. Frontiers in Development Policy, September, p.131-133, 2011.

O'DRISCOLL, G.P.; RIZZO, M.J. The Economics of Time and Ignorance. London and New York: Routledge, 1985. 
PHELPS, Edmund S. Mass Flourishing: How Grassroots Innovation Created Jobs, Challenge and Change. Princeton University Press, 2015.

ROSTOW, W. The Take-Off Into Self-Sustained Growth. The Economic Journal, v. 66, n. 261, p. 25-48, March, 1956.

ROTHBARD, M. N. Man, Economy, and State. Auburn: The Ludwig von Mises Institute, 2001.

SALERNO, J. Money. Sound and Unsound. Auburn: The Ludwig von Mises Institute, 2010.

SCHNEIDER, H. An Austrian view on the middle income trap, Journal of Chinese Economic and Business Studies, v.11, n,3, p. 169-178, 2013.

SCHUMPETER, J. A. Theorie der wirtschaftlichen Entwicklung. Berlin. Duncker \& Humblot 2006: Nachdruck der 1. Auflage von, 1912 (reprint of the first edition)

a b SCHUMPETER, J. A. Capitalism, Socialism and Democracy. London and New York: Routledge, 1994 [1942].

SELGIN, G. Less Than Zero: The Case for a Falling Price Level in a Growing Economy. Auburn: The Ludwig von Mises Institute, 1997.

SHENOY, S. R. Austrian Capital Theory and the Undeveloped Areas: An Overview. In: EBELING, R. (ed.). Austrian Economics: Perspectives on the Past and Prospects for the Future. Champions of Freedom: The Ludwig von Mises Lecture Series. Hillsdale College: Hillsdale College Press, 1991, p. 379-423.

SOTO, J. H. de. Dinero, Crédito Bancario y Ciclos Económicos. Madrid: Unión Editorial. Auburn: The Ludwig von Mises Institute. 2006 [1998].

$\underline{a} \underline{b} \leq$ WORLD BANK. Avoiding Middle-Income Growth Trap. The World Bank. Economic Premise Poverty Reduction and Economic Management Network. Washington: 2012. Available at: $<$ https://openknowledge.worldbank.org/bitstream/handle/10986/16954/NonAsciiFileName0.pdf?se quence=1\&isAllowed=y>. Retrieved October 16, 2018 
WORLD BANK. Team, using data from Penn World Table, version 8.1, 2017. Available at: $<$ https://openknowledge.worldbank.org/bitstream/handle/10986/25880/9781464809507 Spot06.pd f?sequence $=41 \&$ isAllowed $=y>$. Acessed in:

WORLD BANK. The World Bank, Country Classification, 2018. Available at: <https://datahelpdesk.worldbank.org/knowledgebase/articles/906519>. Acessed in: 